\title{
Do Cervical Epidural Injections Provide Long-Term Relief in Neck And Upper Extremity Pain? A Systematic Review
}

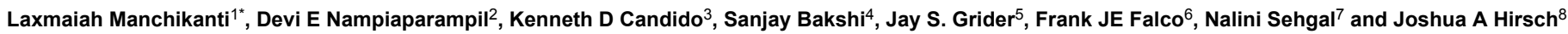
${ }^{1}$ Pain Management Center of Paducah, Paducah, KY, and University of Louisville, USA

${ }^{2}$ New York University School of Medicine, New York, USA

${ }^{3}$ Department of Anesthesiology, Advocate Illinois Masonic Medical Center, Chicago, USA

${ }^{4}$ Manhattan Spine and Pain Medicine, New York, USA

${ }^{5}$ UK Healthcare Pain Services, University of Kentucky, Lexington, USA

${ }^{6}$ Mid Atlantic Spine \& Pain Physicians, Newark, DE, and Temple University Hospital, Philadelphia, USA

${ }^{7}$ University of Wisconsin School of Medicine and Public Health, Madison, USA

${ }^{8}$ Massachusetts General Hospital and Harvard Medical School, Boston, USA

*Corresponding author: Laxmaiah Manchikanti, Pain Management Center of Paducah, Paducah, KY, and University of Louisville, USA, Tel: 270-554-8373; E-mail: drlm@thepainmd.com

Rec date: Jun 19, 2014, Acc date: Sep 16, 2014, Pub date: Sep 18, 2014

Copyright: (c) 2014 Manchikanti L, et al. This is an open-access article distributed under the terms of the Creative Commons Attribution License, which permits unrestricted use, distribution, and reproduction in any medium, provided the original author and source are credited.

\begin{abstract}
Summary of Background Data: The high prevalence of chronic persistent neck pain not only leads to disability but also has a significant economic, societal, and health impact. Among multiple modalities of treatments prescribed in the management of neck and upper extremity pain, surgical, interventional and conservative modalities have been described. Cervical epidural injections are also common modalities of treatments provided in managing neck and upper extremity pain. They are administered by either an interlaminar approach or transforaminal approach.
\end{abstract}

Objectives: To determine the long-term efficacy of cervical interlaminar and transforaminal epidural injections in the treatment of cervical disc herniation, spinal stenosis, discogenic pain without facet joint pain, and post-surgery syndrome.

Materials and Methods: The literature search was performed from 1966 to April 2014 utilizing data from PubMed, Cochrane Library, US National Guideline Clearinghouse, previous systematic reviews, and crossreferences. The evidence was assessed based on best evidence synthesis with Level I to Level V.

Results: There were 7 manuscripts meeting inclusion criteria. Of these, 4 assessed the role of interlaminar epidural injections for managing disc herniation or radiculitis, and 3 assessed these injections for managing central spinal stenosis, discogenic pain without facet joint pain, and post surgery syndrome. There were 4 high quality manuscripts. A qualitative synthesis of evidence showed there is Level II evidence for each etiology category. The evidence is based on one relevant, high quality trial supporting the efficacy of cervical interlaminar epidural injections for each particular etiology. There were no randomized trials available assessing the efficacy of cervical transforaminal epidural injections.

Conclusion: This systematic review with qualitative best evidence synthesis shows Level II evidence for the efficacy of cervical interlaminar epidural injections with local anesthetic with or without steroids, based on at least one high-quality relevant randomized control trial in each category for disc herniation, discogenic pain without facet joint pain, central spinal stenosis, and post-surgery syndrome.

Keywords: Chronic neck pain; Cervical disc herniation; Cervical spinal stenosis; Cervical post-surgery syndrome; Cervical discogenic pain; Cervical epidural injections; Interlaminar epidural injections; Transforaminal epidural injections; Steroids; Local anesthetic

\section{Introduction}

Annual estimates of the prevalence of chronic neck pain in the general population of adults ranges from $12.1 \%$ to $71.5 \%$ with most estimates showing an annual prevalence between $30 \%$ and $50 \%$ with or without sprain or injury [1-7]. Côté et al. [7] described various grades of chronic neck pain with $5 \%$ of patients suffering from Grades III and IV neck pain, both of which are associated with high pain intensity and disability. Overall, they showed the prevalence and impact of neck pain on general health involving $15 \%$ of patients reporting Grade II-IV neck pain. Grade II has been defined as high pain intensity with few activity limitations [7]. Similar to low back pain, neck pain is associated with significant economic, societal, and health impact [8-11]. In fact, a report on the state of U.S. health from 1990-2010 describing the burden of diseases, injuries, and risk factors, showed low back pain as the number one disease leading to disability in 1990 and again in 2010, whereas neck pain ranked number 4 during the 
same period. In addition, chronic pain as a result of motor vehicle injuries has been shown to be present in $24 \%$ to $50 \%$ of those involved in motor vehicle injuries $[6,12,13]$.

Neck and upper extremity pain with headache have been shown to be caused by intervertebral discs, cervical facet joints, ligaments, fascia, muscles, and nerve root dura which are capable of transmitting pain. Even though cervical radicular pain receives the most attention [6,14-21], multiple other mechanisms have been described as being responsible for neck and upper extremity pain. Prevalence studies of various structures causing neck and upper extremity pain show an annual incidence of cervical radicular pain of 83 per 100,000 populations [17]. The prevalence of facet joint pain based on controlled diagnostic blocks in patients with neck pain is $36 \%$ to $67 \%$ [6,22], and $16 \%$ to $20 \%$ for cervical discogenic pain [23]. The pathogenesis of cervical radicular pain or discogenic pain has been linked to multiple chemicals including metalloproteinases, nitric oxide, interleukin-6, and prostaglandin E2 all of which are irritants of the spinal nerves causing inflammation $[6,15,16,18,21]$. Cervical epidural injections are among the treatments described in managing neck and upper extremity pain of disc and nerve irritation without involvement of facet joints. Cervical epidural injections are performed utilizing either an interlaminar or transforaminal approach $[6,19,20]$ and are one of the fastest growing modalities of interventional techniques in managing chronic neck pain and upper extremity pain [24-27].

The effectiveness of cervical epidural injections continues to be intensely debated, in particular for conditions other than disc herniation and radicular pain. Cervical transforaminal epidural injections or selective nerve root blocks are associated with high complication rates and intense debate $[6,19,20,28-43]$. Complications with interlaminar epidural injections, though reported, are considered much less frequent or fatal compared to cervical transforaminal epidural injections. The important differences between interlaminar and transforaminal epidural injections include that while interlaminar entry delivers the medication close to the assumed site of pathology and the transforaminal approach is the target-specific modality requiring the smallest volume to reach the primary site of pathology and also leading to the site of pathology ventrally.

In addition, numerous complications described in recent years, such as fungal infections in compounded steroids leading to devastating complications [41] and the FDA warning on April 23, 2014 concerning injecting corticosteroids into the epidural space of the spine resulting in rare, but serious adverse events, have led to further controversy and discussions [42,43].

Multiple systematic reviews and guidelines performed by various groups of authors have reached different conclusions about the level of evidence for the effectiveness of cervical epidural injections in managing not only disc herniation and radiculitis, but also other conditions $[6,19,20,44,45]$. Among the systematic reviews, Diwan et al. [20] identified 34 studies assessing interlaminar epidural injections with the inclusion of 7 randomized trials in the analysis. They concluded that for cervical disc herniation the evidence was good, whereas for axial or discogenic pain, central spinal stenosis, and postsurgery syndrome the evidence was fair. Other reviews were insufficient with multiple deficiencies.

Consequently, this systematic review was undertaken to determine the long-term efficacy of cervical interlaminar and transforaminal epidural injections in the treatment of disc herniation, spinal stenosis, discogenic pain without facet joint pain, and cervical post-surgery syndrome. We utilized only randomized control trials (RCT), either placebo-controlled or active-controlled.

\section{Materials and Methods}

The methodology utilized in the systematic review followed the review process derived from evidence-based systematic reviews and meta-analysis of randomized trials [46,47].

The literature search was performed from 1966 to April 2014 utilizing data from PubMed, Cochrane Library, US National Guideline Clearinghouse, previous systematic reviews, and cross-references.

\section{Search strategy}

The search strategy emphasized disc herniation, radiculitis, radicular pain, cervicobrachialgia, spinal stenosis, discogenic pain, and post-surgery syndrome in the cervical region or upper extremity pain treated with either interlaminar or transforaminal epidural injections. Search terminology was as follows:

((()((()((post laminectomy) OR post-surgery pain) OR discogenic) OR spinal stenosis) OR radiculitis) OR radiculopathy) OR disc herniation) OR upper extremity) OR cervicobrachialgia)) AND (((transforaminal) OR interlaminar) OR epidural)) AND ((upper extremity) OR cervical) filters: Humans

\section{Inclusion criteria}

Only adults at least 18 years of age with chronic neck and upper extremity pain of at least 3 months duration were included. Furthermore, participants must have failed previous pharmacotherapy, exercise therapy, physical therapy, etc. prior to treatment with interventional pain management techniques. Only appropriately performed cervical epidural injections were included.

\section{Outcome measures}

The primary outcome measure was pain relief and the secondary outcome measure was functional status improvement. Other aspects were also reviewed including psychological status, return to work, reduction or elimination of opioid use, other drugs, or other interventions; and complications. All trials showing a 50\% or more reduction of pain or at least a 3 point decrease in pain scores in at least $50 \%$ of patients were considered as providing efficacy. Short-term improvement was considered as less than 6 months and long-term was considered as 6 months or longer.

\section{Data collection and analysis}

A uniform unblinded search strategy was applied. Studies with at least 3 months of outcome measures with appropriate statistical evaluations were reviewed.

At least 2 of the review authors independently, in an unblinded standardized manner, performed the literature search, analyzed the search data, and selected the trials for inclusion. A third author and consensus resolved any disagreements between reviewers.

\section{Methodologic quality or risk of bias assessment}

Methodological quality or risk of bias assessment of each individual manuscript was performed using Cochrane review criteria (Appendix 
1) for RCTs [48] and interventional pain management quality and risk of bias assessment (Appendix 2) for RCTs [49]. Cochrane review criteria have been utilized in a multitude of reviews. Recently, the American Society of Interventional Pain Physicians (ASIPP) developed a specific instrument for interventional techniques called Interventional Pain Management Techniques - Quality Appraisal of Reliability and Risk of Bias Assessment (IPM-QRB).

The quality of each individual article was independently assessed by 2 review authors who assessed the internal validity of all trials in an unblinded standardized manner. Any discrepancies between the 2 review authors were assessed by a third author and settled by consensus. Randomized trials meeting at least 4 of the 12 Cochrane review criteria or achieving a score of 20 of 48 on IPM-QRB criteria were utilized for analysis. Trials meeting 8 of 12 criteria on the Cochrane review or achieving a score of 32 of 48 on IPM-QRB were considered as high-quality trials. Trials meeting 4 to 7 criteria on Cochrane review or achieving a score of 20 to 31 on IPM-QRB were considered as moderate-quality trials; while studies meeting less than 4 criteria on Cochrane review or achieving a score less than 20 on IPMQRB were considered as low quality.

\section{Meta-analysis}

If there were more than 2 homogenous studies in more than 2 trials of interlaminar or transforaminal injections in managing disc herniation and radiculitis, spinal stenosis, discogenic pain, or postsurgery syndrome, meta-analysis was performed.

\section{Analysis of evidence}

The analysis of evidence was performed based on ASIPP's grading of evidence [50] which was developed from Cochrane criteria of evidence synthesis and multiple other criteria including United States Preventive Services Task Force (USPSTF) analysis of evidence criteria as shown in Table 1.

\begin{tabular}{|l|l|}
\hline Level I & $\begin{array}{l}\text { Evidence obtained from multiple relevant high quality randomized } \\
\text { controlled trials }\end{array}$ \\
\hline Level II & $\begin{array}{l}\text { Evidence obtained from at least one relevant high quality randomized } \\
\text { controlled trial or multiple relevant moderate or low quality } \\
\text { randomized controlled trials }\end{array}$ \\
\hline Level III & $\begin{array}{l}\text { Evidence obtained from at least one relevant moderate or low quality } \\
\text { randomized controlled trial study } \\
\text { or } \\
\text { Evidence obtained from at least one relevant high quality non- } \\
\text { randomized trial or observational study with multiple moderate or low } \\
\text { quality observational studies }\end{array}$ \\
\hline Level IV & $\begin{array}{l}\text { Evidence obtained from multiple moderate or low quality relevant } \\
\text { observational studies }\end{array}$ \\
\hline Level V & Opinion or consensus of large group of clinicians and/or scientists. \\
\hline At least $60 \%$ of studies in the direction of the objective being assessed. \\
\hline
\end{tabular}

Table 1: ASIPP grading of evidence

\section{Results}

The results of the search criteria and selection of trials for inclusion in the systematic review are shown in a flow diagram of study selection as recommended by Preferred Reporting Items for Systematic Reviews and Meta-analysis (PRISMA) (Figure 1) [47].

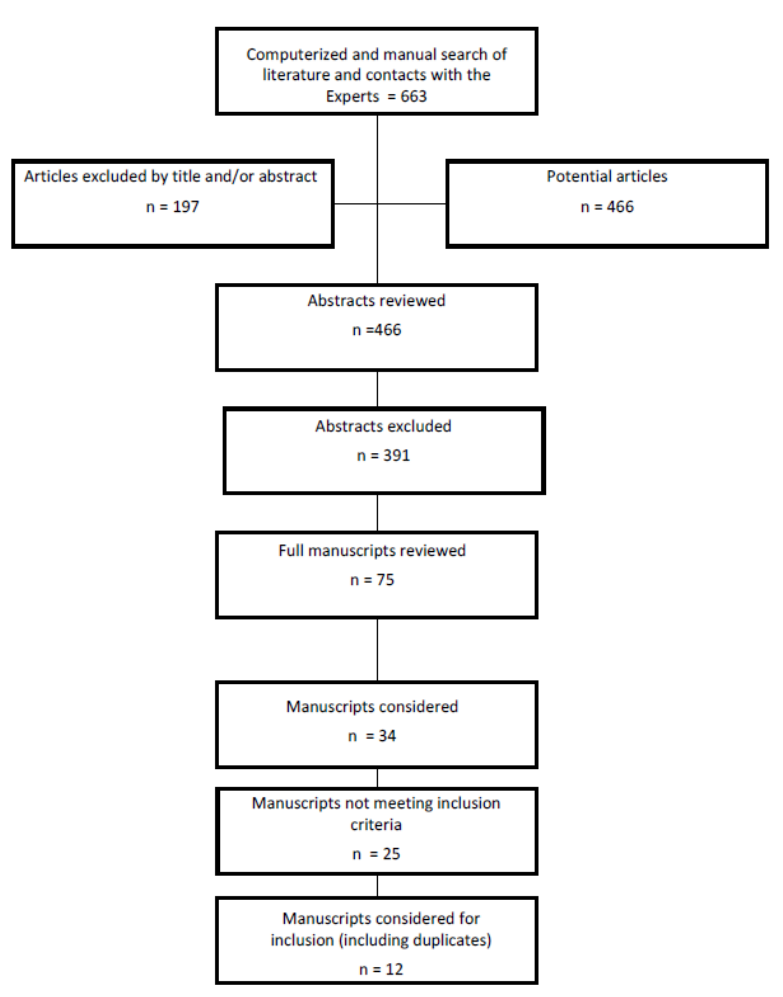

Figure 1: The flow diagram illustrating published literature evaluating cervical interlaminar and transforaminal epidural injections.

Overall, there were 34 manuscripts considered for inclusion; however, only 7 randomized trials, either active-controlled or placebocontrolled met inclusion criteria [51-57]. There were 3 RCTs assessing the transforaminal approach [58-60] which failed to meet the inclusion criteria.

\section{Methodological quality assessment}

A methodological quality assessment of all randomized trials meeting inclusion criteria was performed utilizing Cochrane review criteria as well as ASIPP's IPM-QRB instrument as shown in Tables 2 and 3. After combining duplicates, there were 6 randomized trials evaluating long-term response of 6 months or longer [51-56] with one trial [57] with a follow-up of less than 6 months. Four of the trials were considered as high quality [51-54] based on Cochrane review methodological criteria scores of over 8 , as well as ASIPP's IPM-QRB assessment scores over 32. The other 3 trials were considered moderate quality with scores of 4 to 7 on Cochrane review criteria and 20 to 31 on ASIPP's IPM-QRB [55-57]. 
Citation: Manchikanti L, Nampiaparampil DE, Candido KD, Bakshi S, Grider JS, Falco FJS, et al. (2014) Do Cervical Epidural Injections Provide Long-Term Relief in Neck And Upper Extremity Pain? A Systematic Review. J Spine 3: 177. doi:10.4172/2165-7939.1000177

Page 4 of 13

\begin{tabular}{|c|c|c|c|c|c|c|c|}
\hline & $\begin{array}{l}\text { Manchikanti et } \\
\text { al. [51] }\end{array}$ & $\begin{array}{l}\text { Manchikanti et } \\
\text { al. [52] }\end{array}$ & $\begin{array}{l}\text { Manchikanti et } \\
\text { al. [53] }\end{array}$ & $\begin{array}{l}\text { Manchikanti et } \\
\text { al. [54] }\end{array}$ & $\begin{array}{l}\text { Castagnera et } \\
\text { al. [55] }\end{array}$ & $\begin{array}{l}\text { Stav et al. } \\
{[56]}\end{array}$ & $\begin{array}{l}\text { Pasqualucci et } \\
\text { al. [57] }\end{array}$ \\
\hline Randomization adequate & Y & $\mathrm{Y}$ & $\mathrm{Y}$ & Y & $U$ & $N$ & $N$ \\
\hline Concealed treatment allocation & Y & $\mathrm{Y}$ & $\mathrm{Y}$ & Y & $U$ & $N$ & $N$ \\
\hline Patient blinded & $\mathrm{Y}$ & $\mathrm{Y}$ & $\mathrm{Y}$ & Y & $U$ & $\mathrm{~N}$ & $N$ \\
\hline Care provider blinded & $\mathrm{Y}$ & $\mathrm{Y}$ & $\mathrm{Y}$ & $\mathrm{Y}$ & u & $\mathrm{N}$ & $N$ \\
\hline Outcome assessor blinded & $\mathrm{N}$ & $N$ & $N$ & $\mathrm{~N}$ & $U$ & $N$ & $N$ \\
\hline Drop-out rate described & $\mathrm{Y}$ & $\mathrm{Y}$ & $\mathrm{Y}$ & Y & $\mathrm{Y}$ & $\mathrm{Y}$ & $\mathrm{Y}$ \\
\hline All randomized participants analyzed in the group & Y & $\mathrm{Y}$ & $\mathrm{Y}$ & Y & Y & $\mathrm{Y}$ & Y \\
\hline $\begin{array}{l}\text { Reports of the study free of suggestion of } \\
\text { selective outcome reporting }\end{array}$ & Y & $\mathrm{Y}$ & $\mathrm{Y}$ & Y & $\mathrm{Y}$ & $\mathrm{Y}$ & $\mathrm{Y}$ \\
\hline $\begin{array}{l}\text { Groups similar at baseline regarding most } \\
\text { important prognostic indicators }\end{array}$ & Y & $N$ & $\mathrm{~N}$ & $\mathrm{~N}$ & $\mathrm{Y}$ & $\mathrm{Y}$ & $\mathrm{Y}$ \\
\hline Co-interventions avoided or similar & Y & $\mathrm{Y}$ & $\mathrm{Y}$ & Y & Y & $\mathrm{Y}$ & Y \\
\hline Compliance acceptable in all groups & $\mathrm{Y}$ & $\mathrm{Y}$ & $\mathrm{Y}$ & Y & $\mathrm{Y}$ & $\mathrm{Y}$ & $\mathrm{Y}$ \\
\hline Time of outcome assessment in all groups similar & Y & $\mathrm{Y}$ & $\mathrm{Y}$ & Y & Y & Y & Y \\
\hline Score & 12-Nov & $12-$ Oct & $12-$ Oct & 12-Oct & 12-Jul & 12-Jul & 12-Jul \\
\hline
\end{tabular}

Table 2: Methodological quality assessment of randomized trials utilizing Cochrane review criteria

\begin{tabular}{|c|c|c|c|c|c|c|c|c|}
\hline & & $\begin{array}{l}\text { Manchikanti et } \\
\text { al. [51] }\end{array}$ & $\begin{array}{l}\text { Manchikanti et } \\
\text { al. [52] }\end{array}$ & $\begin{array}{l}\text { Manchikanti et } \\
\text { al. [53] }\end{array}$ & $\begin{array}{l}\text { Manchikanti et } \\
\text { al. [54] }\end{array}$ & $\begin{array}{l}\text { Castagnera et } \\
\text { al. [55] }\end{array}$ & $\begin{array}{l}\text { Stav et al. } \\
{[56]}\end{array}$ & $\begin{array}{l}\text { Pasqualucci et } \\
\text { al. [57] }\end{array}$ \\
\hline I. & \multicolumn{3}{|l|}{ CONSORT OR SPIRIT } & & & & & \\
\hline 1 & Trial Design Guidance and Reporting & 3 & 3 & 3 & 3 & 1 & 1 & 1 \\
\hline II. & \multicolumn{2}{|l|}{ DESIGN FACTORS } & & & & & & \\
\hline 2 & Type and Design of Trial & 2 & 2 & 2 & 2 & 2 & 2 & 2 \\
\hline 3 & Setting/Physician & 2 & 2 & 2 & 2 & 1 & 1 & 1 \\
\hline 4 & Imaging & 3 & 3 & 3 & 3 & 0 & 0 & 0 \\
\hline 5 & Sample Size & 3 & 3 & 2 & 2 & 0 & 0 & 0 \\
\hline 6 & Statistical Methodology & 1 & 1 & 1 & 1 & 1 & 1 & 1 \\
\hline III. & \multicolumn{2}{|l|}{ PATIENT FACTORS } & & & & & & \\
\hline 7 & Inclusiveness of Population & 2 & 2 & 2 & 2 & 2 & 2 & 2 \\
\hline 8 & Duration of Pain & 2 & 2 & 2 & 2 & 2 & 2 & 1 \\
\hline 9 & Previous Treatments & 2 & 2 & 2 & 2 & 2 & 2 & 2 \\
\hline 10 & $\begin{array}{l}\text { Duration of Follow-up with Appropriate } \\
\text { Interventions }\end{array}$ & 3 & 3 & 2 & 2 & 1 & 1 & 1 \\
\hline IV. & \multicolumn{2}{|l|}{ OUTCOMES } & & & & & & \\
\hline 11 & $\begin{array}{l}\text { Outcomes Assessment Criteria for } \\
\text { Significant Improvement }\end{array}$ & 4 & 4 & 4 & 4 & 2 & 2 & 2 \\
\hline
\end{tabular}


Citation: Manchikanti L, Nampiaparampil DE, Candido KD, Bakshi S, Grider JS, Falco FJS, et al. (2014) Do Cervical Epidural Injections Provide Long-Term Relief in Neck And Upper Extremity Pain? A Systematic Review. J Spine 3: 177. doi:10.4172/2165-7939.1000177

Page 5 of 13

\begin{tabular}{|c|c|c|c|c|c|c|c|c|}
\hline 12 & $\begin{array}{l}\text { Analysis of all Randomized Participants } \\
\text { in the Groups }\end{array}$ & 2 & 2 & 2 & 2 & 2 & 2 & 2 \\
\hline 13 & Description of Drop Out Rate & 2 & 2 & 2 & 2 & 2 & 2 & 2 \\
\hline 14 & $\begin{array}{l}\text { Similarity of Groups at Baseline for } \\
\text { Important Prognostic Indicators }\end{array}$ & 0 & 1 & 1 & 1 & 1 & 1 & 1 \\
\hline 15 & Role of Co-Interventions & 1 & 1 & 1 & 1 & 1 & 1 & 1 \\
\hline V. & RANDOMIZATION & & & & & & & \\
\hline 16 & Method of Randomization & 2 & 2 & 2 & 2 & 0 & 0 & 0 \\
\hline VI. & ALLOCATION CONCEALMENT & & & & & & & \\
\hline 17 & Concealed Treatment Allocation & 2 & 2 & 2 & 2 & 0 & 0 & 0 \\
\hline VII. & BLINDING & & & & & & & \\
\hline 18 & Patient Blinding & 1 & 1 & 1 & 1 & 0 & 0 & 0 \\
\hline 19 & Care Provider Blinding & 1 & 1 & 1 & 1 & 0 & 0 & 0 \\
\hline 20 & Outcome Assessor Blinding & 0 & 0 & 0 & 0 & 0 & 0 & 0 \\
\hline VIII. & CONFLICTS OF INTEREST & & & & & & & \\
\hline 21 & Funding and Sponsorship & 2 & 2 & 2 & 2 & 2 & 2 & 2 \\
\hline 22 & Conflicts of Interest & 3 & 3 & 3 & 3 & 3 & 3 & 3 \\
\hline \multicolumn{2}{|c|}{ TOTAL MAXIMUM } & 43 & 44 & 42 & 42 & 25 & 25 & 24 \\
\hline
\end{tabular}

Table 3: Methodologic quality assessment of randomized trials utilizing ASIPPs utilizing IPM - QRB

\section{Characteristics of included trials}

Of the 7 included trials of interlaminar epidural injections, 4 assessed patients with disc herniation [51,55-57], one trial included patients with disc related axial pain without disc herniation or radiculitis [52], one trial included patients with central spinal stenosis [53], and one trial assessed patients with post-surgery syndrome [54]. All of the trials were of an active control design. Only one trial had follow-up of less than 6 months [57]. There were no true placebocontrolled trials. One trial did identify itself a placebo-controlled design utilizing intramuscular steroids in the control group [58]. There were no trials of transforaminal epidural injections in the cervical spine meeting inclusion criteria for methodological quality assessment.

\section{Study characteristics}

Table 4 describes study characteristics and results of RCTs of cervical interlaminar epidurals.

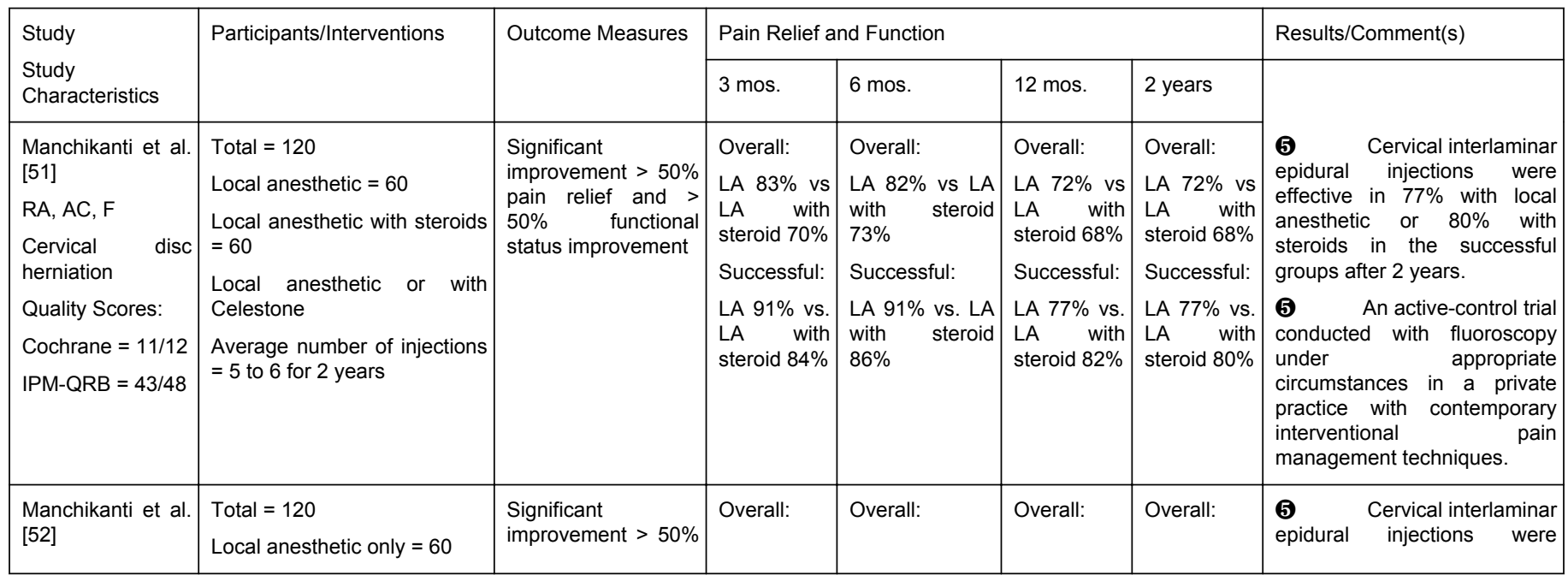


Citation: Manchikanti L, Nampiaparampil DE, Candido KD, Bakshi S, Grider JS, Falco FJS, et al. (2014) Do Cervical Epidural Injections Provide Long-Term Relief in Neck And Upper Extremity Pain? A Systematic Review. J Spine 3: 177. doi:10.4172/2165-7939.1000177

Page 6 of 13

\begin{tabular}{|c|c|c|c|c|c|c|c|}
\hline $\begin{array}{l}\text { RA, AC, F } \\
\text { Cervical } \\
\text { discogenic pain } \\
\text { Quality Scores: } \\
\text { Cochrane }=10 / 12 \\
\text { IPM-QRB }=44 / 48\end{array}$ & $\begin{array}{l}\text { Local anesthetic with steroids } \\
=60 \\
\text { Local anesthetic or with } \\
\text { Celestone } \\
\text { Average number of injections } \\
=5 \text { to } 6 \text { for } 2 \text { years }\end{array}$ & $\begin{array}{l}\text { pain relief and }>50 \% \\
\text { functional } \\
\text { improvement }\end{array}$ & $\begin{array}{l}\text { LA } 68 \% \text { vs } \\
\text { LA rith } \\
\text { steroid } 77 \% \\
\text { Successful: } \\
\text { LA } 75 \% \text { vs. } \\
\text { LA } \quad \text { with } \\
\text { steroid } 82 \%\end{array}$ & $\begin{array}{l}\text { LA } 67 \% \text { vs LA } \\
\text { with } \quad \text { steroid } \\
73 \% \\
\text { Successful: } \\
\begin{array}{ll}\text { LA } 73 \% & \text { vs. LA } \\
\text { with } & \text { steroid } \\
79 \% & \end{array}\end{array}$ & $\begin{array}{l}\text { LA } 72 \% \text { vs } \\
\text { LA } \quad \text { with } \\
\text { steroid } 68 \% \\
\text { Successful: } \\
\text { LA } 78 \% \text { vs. } \\
\text { LA } \quad \text { with } \\
\text { steroid } 73 \%\end{array}$ & $\begin{array}{l}\text { LA } 73 \% \text { vs } \\
\text { LA with } \\
\text { steroid } 70 \% \\
\text { Successful: } \\
\text { LA } 78 \% \text { vs. } \\
\text { LA with } \\
\text { steroid } 75 \%\end{array}$ & $\begin{array}{l}\text { effective in } 78 \% \text { with local } \\
\text { anesthetic or } 75 \% \text { with } \\
\text { steroids in the successful } \\
\text { groups after } 2 \text { years. } \\
\mathbf{5} \text { An active-control trial } \\
\text { conducted with fluoroscopy } \\
\text { under appropriate } \\
\text { circumstances in a private } \\
\text { practice with contemporary } \\
\text { interventional pain } \\
\text { management techniques. }\end{array}$ \\
\hline $\begin{array}{l}\text { Manchikanti et al. } \\
{[53]} \\
\text { RA, AC, F } \\
\text { Cervical spinal } \\
\text { stenosis } \\
\text { Quality Scores: } \\
\text { Cochrane }=10 / 12 \\
\text { IPM-QRB }=42 / 48\end{array}$ & $\begin{array}{l}\text { Total }=60 \\
\text { Local anesthetic only }=30 \\
\text { Local anesthetic with steroids } \\
=30 \\
\text { Local anesthetic or with } \\
\text { Celestone } \\
\text { Average number of injections } \\
=3 \text { to } 4 \text { for } 2 \text { years }\end{array}$ & $\begin{array}{l}\text { Significant } \\
\text { improvement }>50 \% \\
\text { pain relief and > } \\
50 \% \text { functional } \\
\text { status improvement }\end{array}$ & $\begin{array}{l}\text { Overall: } \\
\text { LA } 77 \% \text { vs } \\
\text { LA with } \\
\text { steroid } 87 \% \\
\text { Successful: } \\
\text { LA } 79 \% \text { vs. } \\
\text { LA with } \\
\text { steroid } 92 \%\end{array}$ & 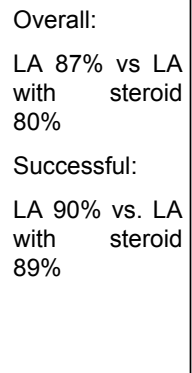 & $\begin{array}{l}\text { Overall: } \\
\text { LA } 73 \% \text { vs } \\
\text { LA r with } \\
\text { steroid } 70 \% \\
\text { Successful: } \\
\text { LA } 76 \% \text { vs. } \\
\text { LA r with } \\
\text { steroid } 77 \%\end{array}$ & NA & $\begin{array}{l}5 \text { Significant pain relief was } \\
\text { seen in } 87 \% \text { in both groups, } \\
\text { while in Group I, } 77 \% \text { and in } \\
\text { Group II, } 87 \% \text { had functional } \\
\text { status improvement. } \\
5 \text { An active-control trial } \\
\text { conducted with fluoroscopy } \\
\text { under appropriate } \\
\text { circumstances in a private } \\
\text { practice with contemporary } \\
\text { interventional pain } \\
\text { management techniques. }\end{array}$ \\
\hline $\begin{array}{l}\text { Manchikanti et al. } \\
{[54]} \\
\text { RA, AC, F } \\
\text { Cervical post } \\
\text { surgery syndrome } \\
\text { Quality Scores: } \\
\text { Cochrane }=10 / 12 \\
\text { IPM-QRB }=42 / 48\end{array}$ & $\begin{array}{l}\text { Total }=56 \\
\text { Local anesthetic only }=28 \\
\text { Local anesthetic with steroids } \\
=28 \\
\text { Local anesthetic or with } \\
\text { Celestone } \\
\text { Average number of injections } \\
=3 \text { to } 4 \text { for one year }\end{array}$ & $\begin{array}{l}\text { Significant } \\
\text { improvement }>50 \% \\
\text { pain relief and > } \\
50 \% \text { functional } \\
\text { status improvement }\end{array}$ & $\begin{array}{l}\text { Overall: } \\
\text { LA } 68 \% \text { vs } \\
\text { LA } \quad \text { with } \\
\text { steroid } 68 \% \\
\text { Successful: } \\
\text { LA } 83 \% \text { vs. } \\
\text { LA } \quad \text { with } \\
\text { steroid } 72 \%\end{array}$ & $\begin{array}{l}\text { Overall: } \\
\text { LA } 64 \% \text { vs LA } \\
\text { with steroid } \\
71 \% \\
\text { Successful: } \\
\begin{array}{ll}\text { LA } 78 \% & \text { vs. LA } \\
\text { with } & \text { steroid } \\
80 \% & \end{array}\end{array}$ & $\begin{array}{l}\text { Overall: } \\
\text { LA } 71 \% \text { vs } \\
\text { LA r with } \\
\text { steroid } 64 \% \\
\text { Successful: } \\
\text { LA } 87 \% \text { vs. } \\
\text { LA } \quad \text { with } \\
\text { steroid } 72 \%\end{array}$ & NA & $\begin{array}{l}\text { 6 Cervical interlaminar } \\
\text { epidural injections were } \\
\text { effective in } 87 \% \text { with local } \\
\text { anesthetic or } 72 \% \text { with } \\
\text { steroids in the successful } \\
\text { groups after } 2 \text { years. } \\
\mathbf{5} \text { An active-control trial } \\
\text { conducted with fluoroscopy } \\
\text { under appropriate } \\
\text { circumstances in a private } \\
\text { practice with contemporary } \\
\text { interventional pain } \\
\text { management techniques. }\end{array}$ \\
\hline $\begin{array}{l}\text { Castagnera et al. } \\
{[55]} \\
\text { RA, AC, B } \\
\text { Cervical disc } \\
\text { herniation and } \\
\text { radiculitis } \\
\text { Quality Scores: } \\
\text { Cochrane = 7/12 } \\
\text { IPM-QRB }=25 / 48\end{array}$ & $\begin{array}{l}\text { Total }=24 \\
\text { Local anesthetic }+ \text { steroid }= \\
14 \\
\text { Local anesthetic }+ \text { steroid }+ \\
\text { morphine }=10 \\
\text { Number of injections }=1\end{array}$ & $\begin{array}{l}\text { Pain relief, visual } \\
\text { analog scale, work } \\
\text { status }\end{array}$ & $79.2 \%$ & $79.2 \%$ & $79.2 \%$ & NA & $\begin{array}{l}5 \text { Success rate was } 78.5 \% \\
\text { in the steroid group and } 80 \% \\
\text { in the group with steroids and } \\
\text { morphine. Pain relief } \\
\text { remained stable with time with } \\
\text { long-term follow-up of as } \\
\text { much as } 48 \text { months with } \\
\text { mean of } 43 \pm 18.1 \text { mos. } \\
\text { 5 Results suggested that a } \\
\text { single cervical epidural steroid } \\
\text { injection performed produces } \\
\text { long-lasting pain relief, which } \\
\text { is not improved when } \\
\text { morphine is combined with } \\
\text { steroids. }\end{array}$ \\
\hline $\begin{array}{l}\text { Stav et al. [56] } \\
\text { RA, AC, B } \\
\text { Cervical disc } \\
\text { herniation and } \\
\text { radiculitis } \\
\text { Quality Scores: } \\
\text { Cochrane = } 7 / 12 \\
\text { IPM-QRB }=25 / 48\end{array}$ & $\begin{array}{l}\text { Total }=42 \\
\text { Cervical epidural steroid } / \\
\text { lidocaine injections }=25 \\
\text { Steroid/lidocaine injections } \\
\text { into posterior neck muscles }= \\
17 \\
\text { Number of injections }=1 \text { to } 3\end{array}$ & $\begin{array}{l}\text { Pain relief, change } \\
\text { in range of motion, } \\
\text { reduction of daily } \\
\text { dose of analgesics, } \\
\text { return to work }\end{array}$ & NA & NA & $\begin{array}{ll}68 \% & \text { vs. } \\
11.8 \% & \end{array}$ & NA & $\begin{array}{l}\mathbf{5} \text { One year after the } \\
\text { treatment, } 68 \% \text { of patients } \\
\text { receiving epidural steroid } \\
\text { injections had very good and } \\
\text { good pain relief, whereas only } \\
11.8 \% \text { of group patients with } \\
\text { intramuscular injections } \\
\text { showed improvement. } \\
\mathbf{5} \text { This is a well-performed } \\
\text { randomized active-control } \\
\text { study, even though it was } \\
\text { performed } \\
\text { fluoroscopy. }\end{array}$ \\
\hline $\begin{array}{l}\text { Pasqualucci et al. } \\
{[57]}\end{array}$ & 40 of 160 & $\begin{array}{l}\text { Pain control of } \\
\text { greater than } 80 \% \text {, }\end{array}$ & NA & $\begin{array}{l}\text { Single vs. } \\
\text { continuous }\end{array}$ & NA & NA & $\begin{array}{l}5 \text { There was significant } \\
\text { decrease in pain control and }\end{array}$ \\
\hline
\end{tabular}




\begin{tabular}{|c|c|c|c|c|}
\hline $\begin{array}{l}\mathrm{RA}, \mathrm{AC}, \mathrm{B} \\
\text { Cervical disc } \\
\text { herniation and } \\
\text { radiculitis } \\
\text { Quality Scores: } \\
\text { Cochrane }=7 / 12 \\
\mathrm{IPM}-\mathrm{QRB}=24 / 48\end{array}$ & $\begin{array}{l}\text { Bupivacaine with } \\
\text { methylprednisolone acetate } \\
\text { Patients received a single } \\
\text { injection with } 0.25 \% \\
\text { bupivacaine with epinephrine } \\
1 \text { in } 200,000 \text { in a volume of } 6 \\
\mathrm{~mL} \text { with } 80 \text { mg of } \\
\text { methylprednisolone acetate } \\
\text { every } 4-5 \text { days to a maximum } \\
\text { of } 8 \text { blocks. Continuous } \\
\text { epidural group patients } \\
\text { received catheterization with } \\
\text { repeat injection 12-24 hours } \\
\text { and steroids } 4-5 \text { days. }\end{array}$ & $\begin{array}{l}\text { pain-free hours of } \\
\text { sleep }\end{array}$ & $\begin{array}{l}58.5 \%, \quad 73.7 \% \\
\text { improvement }\end{array}$ & $\begin{array}{l}\text { increase of pain-free sleep } \\
\text { with single as well as } \\
\text { continued administrations in } \\
\text { approximately } 17 \text { of } 20 \\
\text { patients with single injection } \\
\text { and } 17 \text { of } 20 \text { patients with } \\
\text { continuous infusion at one } \\
\text { month and } 6 \text { mos. }\end{array}$ \\
\hline
\end{tabular}

Table 4: Study characteristics and results of cervical interlaminar randomized controlled trials

\section{Disc herniation and radiculitis}

A total of 4 studies met the inclusion criteria and evaluated the role of cervical interlaminar epidural injections in disc herniation or radiculitis [51,57-59]. There was only one high quality randomized trial performed with an active-controlled design under fluoroscopic guidance [51]. The remaining 3 studies of the epidural injections were performed blindly [57-59]; one study described as a placebo-controlled design, administered steroids in the control group [58]. Yet another study utilized morphine as an additive to the injected solution [57]. Finally, the last study [59] compared continuous versus single epidural injections providing up to approximately 8 injections in the single group and assessed pain relief for only 6 month. The quality of these 3 studies performed without fluoroscopy was moderate.

Only one out of four randomized trial enrolled 120 participants with 60 subjects in each group, either with local anesthetic alone or local anesthetic plus steroids.

All the studies showed significant improvement compared to baseline, while there was no significant improvement among the groups, except in the study by Stav et al [56] where intramuscular steroid injections served as controls. However, this study enrolled only a small number of patients and provided only one injection. These results have not been replicated with improvement in a significant proportion of patients with only one epidural injection. The largest randomized trial by Manchikanti et al [51] showed significant improvement from the baseline at all levels, including function as well as disability. Of the 4 randomized trials meeting the inclusion criteria evaluating cervical interlaminar epidural injections, all of them showed positive results for the long-term; however, there was only one study for which the results were strong [51].

\section{Axial or discogenic pain}

There was only one study evaluating axial discogenic pain and the role of cervical interlaminar epidural injections in patients without disc herniation, radiculitis, or facet joint arthropathy [52]. This study showed positive results. This was a large study performed in a contemporary interventional management practice setting utilizing an active-controlled design with 60 patients in each group. This study showed positive results at all levels whether local anesthetic was utilized alone or combined with steroids, both in pain relief as well as functional status.

\section{Spinal stenosis}

There was only one randomized trial meeting the inclusion criteria in the evaluation of central spinal stenosis in the cervical spine [53]. This study was of an active-controlled design and a preliminary report, but showed positive results.

\section{Post-surgery syndrome}

There was only one randomized trial evaluating the effectiveness of cervical interlaminar epidural injections in post-surgery syndrome with or without steroids with an active-controlled design, but with preliminary results [54]. The results were positive at 3, 6, and 12 months both for pain and functional status with or without steroids.

\section{Meta-analysis}

No meta-analysis was performed, as none of the trials were homogenous for a specific condition. Only cervical disc herniation and radiculitis had a multiplicity of trials; although they were not homogenous. Among the 4 trials, one study compared local anesthetic with local anesthetic and steroids, a second study compared local anesthetic with steroids or steroid plus morphine, and the third trial compared local anesthetic with steroid or intramuscular steroids, and the fourth trial compared bupivacaine with methylprednisolone acetate in a short-term follow-up. In addition, follow-up was 2 years for one trial [51], one year for 2 of the trials $[55,56]$, and only 6 months for one trial [57]. Only one of the 4 trials [51] was conducted with fluoroscopy. The methodologic quality assessment also showed differences with one trial being high quality [51] and the remaining trials being moderate quality [55-57].

\section{Analysis of evidence}

Since there was no meta-analysis feasible, qualitative evidence was synthesized based on the specific condition for which the cervical interlaminar epidural injections were provided. Table 4 shows the results of all the included randomized trials with the effectiveness of interlaminar epidural injections for 4 specific conditions, namely, disc herniation or radiculitis, axial or discogenic pain, central spinal stenosis, and post-surgery syndrome. 


\section{Level of evidence}

Based on ASIPP's grading of evidence criteria, the evidence is considered at 5 levels [50].

\section{Cervical disc herniation}

For cervical disc herniation or radiculitis, based on one relevant high quality, large fluoroscopically directed active-controlled trial with local anesthetic with or without steroids [51], in conjunction with 3 moderate quality smaller randomized trials with positive results [55-57], the evidence is Level II supporting the benefit of cervical interlaminar epidural injections.

\section{Axial or discogenic pain}

For cervical axial or discogenic pain without facet joint pain, based on one relevant high-quality, large fluoroscopically directed activecontrolled trial with local anesthetic with or without steroids [54], the evidence is Level II supporting the benefit of cervical interlaminar epidural injections.

\section{Spinal stenosis}

For cervical central spinal stenosis or cervical radiculitis, based on one relevant high-quality, fluoroscopically directed active-controlled trial with local anesthetic with or without steroids [53], the evidence is Level II supporting the benefit of cervical interlaminar epidural injections.

\section{Post-surgery syndrome}

For cervical post-surgery syndrome based on one relevant highquality, fluoroscopically directed active-controlled trial with local anesthetic with or without steroids [53], the evidence is Level II supporting the benefit of cervical interlaminar epidural injections.

\section{Summary of evidence}

In summary, there is Level II evidence for cervical interlaminar epidural injections administered in managing disc herniation, central spinal stenosis, discogenic pain, and post-surgery syndrome with local anesthetic with or without steroids based on high-quality RCTs.

\section{Discussion}

This systematic review on the effectiveness of cervical epidural injections in managing chronic neck pain with or without upper extremity pain assessed the efficacy of interlaminar epidural injections. There were, however, no randomized trials available for cervical transforaminal epidural injections. Based on relevant high-quality RCTs, the evidence shown here is Level II with at least one RCT for each pathologic condition, namely - cervical disc herniation and radiculitis, cervical central spinal stenosis, discogenic pain without facet joint pain or disc herniation, and cervical post-surgery syndrome utilizing local anesthetic alone or with steroids.

Cervical disc herniation is readily diagnosed and one of the most common indications for surgical interventions in the spine. It is also believed that the course and prognosis of any spinal pain secondary to disc herniation and other causes are favorable; however, some patients continue to have persistent and disabling symptoms 2 years or longer and many undergo surgery. A multitude of surgical interventions in managing neck pain are becoming increasingly popular. The utilization of surgical interventions has increased 8-fold for anterior cervical discectomy and fusion from 1990 to 2004 with a 28-fold increase in those over 65 years of age [61]. Overall there is concern about increasing surgical interventions and the success rate of these interventions, as they frequently result in post cervical surgery syndrome [62-70].

Similarly, assessments in Medicare populations [24-27] showed an increase of $142 \%$ from 2000 to 2011 per 100,000 Medicare beneficiaries of cervical and thoracic transforaminal epidural injections and $123 \%$ of cervical and thoracic interlaminar epidural injections [24]. However, these increases are significantly less than other cervical and thoracic facet joint interventions, which showed respective increases of $359 \%$ for cervical and thoracic facet joint nerve blocks and $836 \%$ for cervical and thoracic neurolytic procedures [27]. Overall, the contribution of thoracic spine interventions is considered minor compared to cervical spine ailments.

The results of this systematic review are similar to some previous reviews $[19,20]$; they do not, however, correlate with other reviews that have not been performed appropriately due to an inadequate literature search. Furthermore, the results from lumbar epidural injections have also been reciprocated to the cervical spine. While the results may be similar in the entire spine, whether it is cervical, lumbar or thoracic, the evidence in the lumbar spine has been inappropriately synthesized. Of importance, the systematic review by Pinto et al [71] which showed the efficacy of epidural injections for short-term relief without lack of efficacy for long-term. The criteria for long term is arbitrary, most studies use 6 months and greater as long term. Further it is unrealistic to expect one or two ESI to provide long term relief of 12 months or longer in spinal stenosis and compare these outcomes with patients who are on long term analgesic therapy or those who undergo surgery. In contrast, Manchikanti et al [72-74] and others [6,75-78] have shown contradictory results showing the efficacy of epidural injections with caudal, interlaminar, and transforaminal approaches for both the short term and long term when the analysis was performed appropriately. Pinto et al's [71] results have been criticized for multiple deficiencies $[74,77,78]$. Pinto et al was criticized for utilizing methodological quality assessment criteria developed for physiotherapy, that the instrument was not validated for interventional techniques [74,79] and which differed substantially from criteria developed by the Cochrane review group [48]. In contrast, in this systematic review we utilized strict methodological and bias assessment review criteria utilizing the well-established Cochrane review criteria instrument [48], as well as the recently developed IPM-QRB instrument [49], which incorporates all the ingredients necessary in the assessment of interventional techniques. In fact, the deficiencies of Cochrane review criteria have been addressed by others [78]. In addition, Pinto et al [71] also included a multitude of heterogeneous studies that were labeled as homogeneous and conducted meta-analysis leading to inappropriate conclusions [74]. The authors, in fact, have indicated erroneously that the studies were homogeneous based on the fact that reviewers decided that local anesthetic injection was a placebo [74]. Such a methodology invalidates the entire concept of meta-analysis of homogenous studies. Pinto et al [71], similar to others [80-84], have utilized methodologies without attention to any clinical aspects. Pinto et al [71] also failed to consider the varying effects of placebo and nocebo, impure placebo, and the effects of injecting inactive solutions into active structures, concluding that injection of active solutions into active structures was placebo when it did not meet their criteria [6,85-87]. In addition, multiple randomized trials, specifically of 
epidural injections utilizing only local anesthetic [51-54,88-95], have shown significant clinical effects. These effects were equal in the majority of the trials with the exception of a slight superiority in disc herniation confirmed by experimental studies $[96,97]$ and a systematic review [78].

The underlying mechanism of action of epidurally administered steroids, local anesthetic the risks of local anesthetic have not been well understood [98-107]. Steroids and local anesthetics have been described to exert their mechanism of action by a neural blockade that alters nociceptive input, the reflex mechanism of afferent fibers, selfsustaining activity of the neurons, and the pattern of central neuronal activities [6]. In addition, corticosteroids have been shown to reduce inflammation by inhibiting either the synthesis or release of a number of proinflammatory mediators and by causing a reversible local anesthetic effect. The emerging evidence also shows the long-lasting effect of local anesthetics. It has been postulated that local anesthetics provide relief by multiple mechanisms that include the suppression of nociceptive discharge, the blockade of sympathetic reflex arc, the blockade of axonal transport, the blockade of sensitization, and antiinflammatory effects [6]. Clinical as well as experimental evidence shows a lack of significant difference between local anesthetic alone or with steroids indicating that corticosteroids may be unnecessary for spinal injections. A common problem encountered with any epidural injection, however, is inaccurate needle placement, as this leads to inaccurate placement of the injectate $[19,20]$. Consequently, proponents for fluoroscopic guidance in epidural injections advocate utilizing this technique in order to assure that medications reach the appropriate desired intervertebral space [108-111]. Furthermore, target specificity of epidural injections has also been questioned in the utilization of interlaminar cervical epidural injections [108-111].

Multiple authors have assessed prognostic factors for cervical epidural injections [112-117]. In a retrospective evaluation [112], the influence of chronic opioid use is shown as a negative predictive factor for response to cervical epidural steroid injections. This concept has been addressed in multiple publications for surgical interventions. In fact, studies have shown that opioid withdrawal is a difficult task [118-121]. Another assessment [114] showed that patients who required narcotics for their symptom management prior to the procedure showed poor pain relief. Radiographic assessment as a prognostic factor was evaluated in 2 assessments [113,122]. In one manuscript [113] it was shown that magnetic resonance imaging (MRI) predicted therapeutic response to epidural injections in patients with cervical radiculopathy and concluded that patients with central canal stenosis achieved a significantly better functional outcome after cervical epidural steroid injections than those without. In contrast, others $[115,116]$ have shown better improvement with disc herniation than spinal stenosis which is also reflected in the findings of lumbar epidural injections.

It is crucial that safety be considered in the utilization of epidural injections [19]. Multiple risks include bleeding, non-fluoroscopic performance of the procedure, heavily sedated patients or those under general anesthesia, and performing the procedure above C5-C6 level [19]. Serious complications can occur including spinal cord trauma or nerve trauma, infection, and epidural hematoma, even though intravascular penetration, subarachnoid puncture, and injection of particulate steroids into the radicular artery are major complications specifically with cervical transforaminal.
Multiple technological modifications have been described to improve the safety and efficacy of transforaminal epidural injections [122-125].

There is a wide array of literature to improve the safety of cervical transforaminal epidural injections with a posterior approach, extraforaminal technique, utilizing special needles and catheters, etc. The detailed description of these aspects is beyond this manuscript [19].

The limitations of this systematic review include the paucity of high-quality literature for each modality, with only a total of 7 RCTs available, 4 of them assessing disc herniation, and one randomized high-quality trial assessing spinal stenosis and discogenic pain and post surgery syndrome. In addition, among the 4 trials available assessing disc herniation, there was only one high-quality trial. Consequently, without homogeneity among the randomized trials, we were unable to perform meta-analysis. In addition, all evidence was obtained from active-controlled trials, specifically for long-term improvement. Active-controlled trials compare 2 different procedures or drugs, thus, some may consider this as a weakness. One trial, described as placebo controlled, used intramuscular steroids, which also is an active-controlled trial. The majority of analytical flaws in evidence synthesis are based on methodologists repeatedly considering one of the drugs as placebo and comparing both drugs or both groups rather than baseline to follow-up periods, which is the only solution in active-controlled trials. Thus, the strengths of active-controlled trials include comparative evaluation, which has become pivotal in modern spine research given the difficulty associated with the design of appropriate placebo-controlled trials. However, there have been descriptions of appropriate placebo design, even in interventional techniques, in recent years with an inactive substance injected into an inactive structure. Thus, even though we considered active-controlled trials as a limitation, there are also multiple strengths to the use of active-controlled trials in deriving the evidence of efficacy. Furthermore, the strength of evidence we provided is qualitative evidence rather than quantitative evidence. We believe that this is appropriate since it is essential to assess the evidence appropriately rather than reach inappropriate conclusions with improper assessment.

The evidence seems to appear somewhat stronger for disc herniation with a multiplicity of studies in support and an absence of any negative studies to contradict these findings, even though only one was of high quality for spinal stenosis, discogenic pain, and post surgery syndrome. There was only one trial in each category that was of high quality. Both long-term studies with a large number of patients assessing disc herniation and discogenic pain were of active control nature.

\section{Conclusion}

This systematic review, with a proper assessment of methodological quality and risk of bias, shows Level II evidence, which supports the benefit of cervical interlaminar epidural injections based on at least one high-quality, relevant RCT for each etiology studied: disc herniation, discogenic pain without facet joint pain or disc herniation, central spinal stenosis, and post-surgery syndrome.

\section{References}

1. Hoy DG, Protani M, De R, Buchbinder R (2010) The epidemiology of neck pain. Best Pract Res Clin Rheumatol 24: 783-792. 
2. Hogg-Johnson S, van der Velde G, Carroll LJ, Holm LW, Cassidy JD et al Bone and Joint Decade 2000 - 2010 Task Force on Neck Pain and Its Associated Disorders (2008) The burden and determinants of neck pain in the general population: Results of the Bone and Joint Decade $2000-$ 2010 Task Force on Neck Pain and its associated disorders. Spine 33: S39S51.

3. Fejer R, Kyvik KO, Hartvigsen J (2006) The prevalence of neck pain in the world population: a systematic critical review of the literature. Eur Spine J 15: 834-848.

4. Leboeuf-Yde C, Fejer R, Nielsen J, Kyvik KO, Hartvigsen J (2012) Pain in the three spinal regions: the same disorder? Data from a populationbased sample of 34,902 Danish adults. Chiropr Man Therap 20: 11.

5. Leboeuf-Yde C, Nielsen J, Kyvik KO, Fejer R, Hartvigsen J (2009) Pain in the lumbar, thoracic or cervical regions: Do age or gender matter? A population-based study of 34,902 Danish twins 20-71 years of age. BMC Musculoskeletal Disorders 10: 39.

6. Manchikanti L, Abdi S, Atluri S, Benyamin RM, Boswell MV, et al. (2013) An update of comprehensive evidence-based guidelines for interventional techniques in chronic spinal pain. Part II: guidance and recommendations. Pain Physician 16: S49-283.

7. Côté P, Cassidy JD, Carroll L (1998) The Saskatchewan Health and Back Pain Survey. The prevalence of neck pain and related disability in Saskatchewan adults. Spine 23: 1689-1698.

8. Martin BI, Deyo RA, Mirza SK, Turner JA, Comstock BA, et al. (2008) Expenditures and health status among adults with back and neck problems. JAMA 299: 656-664.

9. Martin BI, Turner JA, Mirza SK, Lee MJ, Comstock BA, et al. (2009) Trends in health care expenditures, utilization, and health status among US adults with spine problems, 1997-2006. Spine (Phila Pa 1976) 34 2077-2084.

10. Gaskin DJ, Richard P (2012) The economic costs of pain in the United States. J Pain 13: 715-724.

11. US Burden of Disease Collaborators (2013) The state of US health, 1990-2010: burden of diseases, injuries, and risk factors. JAMA 310: 591-608.

12. Cassidy JD, Carroll LJ, Côté P, Lemstra M, Berglund A, et al. (2000) Effect of eliminating compensation for pain and suffering on the outcome of insurance claims for whiplash injury. N Engl J Med 342: 1179-1186.

13. Radanov BP, Sturzenegger M, De Stefano G, Schnidrig A (1994) Relationship between early somatic, radiological, cognitive and psychosocial findings and outcome during a one-year follow-up in 117 patients suffering from common whiplash. Br J Rheumatol 33: 442-448.

14. Bogduk N (1999) Medical Management of Acute Cervical Radicular Pain: An Evidence-based Approach. Newcastle, Cambridge Press.

15. Bogduk N (1999) Pathology. In: Medical Management of Acute Cervical Radicular Pain: An Evidence-Based Approach. Newcastle, Cambridge Press, pp 13-18.

16. Karadimas SK, Klironomos G, Papachristou DJ, Papanikolaou S Papadaki E, et al. (2013) Immunohistochemical profile of NF-ÎI B/p50, NF-Î०B/p65, MMP-9, MMP-2, and u-PA in experimental cervical spondylotic myelopathy. Spine (Phila Pa 1976) 38: 4-10.

17. Radhakrishnan K, Litchy WJ, O'Fallon WM, Kurland LT (1994) Epidemiology of cervical radiculopathy. A population-based study from Rochester, Minnesota, 1976 through 1990. Brain 117 : 325-335.

18. Kang JD, Georgescu HI, McIntyre-Larkin L, Stefanovic-Racic M, Evans CH (1995) Herniated cervical intervertebral discs spontaneously produce matrix metalloproteinases, nitric oxide, interleukin- 6 and prostaglandin E2. Spine 20: 2373-2378.

19. Manchikanti L, Falco FJ, Diwan S, Hirsch JA, Smith HS (2014) Cervical radicular pain: the role of interlaminar and transforaminal epidural injections. Curr Pain Headache Rep 18: 389.

20. Diwan S, Manchikanti L, Benyamin RM, Bryce DA, Geffert S, et al. (2012) Effectiveness of cervical epidural injections in the management of chronic neck and upper extremity pain. Pain Physician 15: E405-434.
21. Park MS, Moon SH, Lee HM, Kim SW, Kim TH, et al. (2013) The natural history of degenerative spondylolisthesis of the cervical spine with 2- to 7-year follow-up. Spine (Phila Pa 1976) 38: E205-210.

22. Falco FJE, Datta S, Manchikanti L, Sehgal N, Geffert S et al (2012) An updated review of diagnostic utility of cervical facet joint injections. Pain Physician 15: E807-E838.

23. Onyewu O, Manchikanti L, Falco FJ, Singh V, Geffert S, et al. (2012) An update of the appraisal of the accuracy and utility of cervical discography in chronic neck pain. Pain Physician 15: E777-806.

24. Manchikanti L, Pampati V, Falco FJ, Hirsch JA (2013) Assessment of the growth of epidural injections in the medicare population from 2000 to 2011. Pain Physician 16: E349-364.

25. Manchikanti L, Pampati V, Falco FJ, Hirsch JA (2013) Growth of spinal interventional pain management techniques: analysis of utilization trends and Medicare expenditures 2000 to 2008. Spine (Phila Pa 1976) 38: 157-168.

26. Manchikanti L, Falco FJ, Singh V, Pampati V, Parr AT, et al. (2012) Utilization of interventional techniques in managing chronic pain in the Medicare population: analysis of growth patterns from 2000 to 2011. Pain Physician 15: E969-982.

27. Manchikanti L, Helm Ii S, Singh V, Hirsch JA (2013) Accountable interventional pain management: a collaboration among practitioners, patients, payers, and government. Pain Physician 16: E635-670.

28. Manchikanti L, Malla Y, Wargo BW, Cash KA, Pampati V et al (2012) A prospective evaluation of complications of 10,000 fluoroscopically directed epidural injections. Pain Physician 15: 131-140.

29. Scanlon GC, Moeller-Bertram T, Romanowsky SM, Wallace MS (2007) Cervical transforaminal epidural steroid injections: More dangerous than we think? Spine 32: 1249-1256.

30. Hodges SD, Castleberg RL, Miller T, Ward R, Thornburg C (1998) Cervical epidural steroid injection with intrinsic spinal cord damage. Two case reports. Spine (Phila Pa 1976) 23: 2137-2142.

31. Bose B (2005) Quadriparesis following cervical epidural steroid injections: case report and review of the literature. Spine J 5: 558-563.

32. Shanthanna H, Park J (2011) Acute epidural haematoma following epidural steroid injection in a patient with spinal stenosis. Anaesthesia 66: 837-839.

33. Singh R, Panagos A (2006) Quadriparesis following cervical epidural steroid injections. Spine J 6: 349.

34. Rathmel JP, Benzon HT (2004) Transforaminal injection of steroids: Should we continue? Reg Anesth Pain Med 29: 297-299.

35. Tiso RL, Cutler T, Catania JA, Whalen K (2004) Adverse central nervous system sequelae after selective transforaminal block: The role of corticosteroids. Spine J 4: 468-474.

36. Ludwig MA, Burns SP (2005) Spinal cord infarction following cervical transforaminal epidural injection: a case report. Spine (Phila Pa 1976) 30: E266-268.

37. Brouwers PJ, Kottink EJ, Simon MA, Prevo RL (2001) A cervical anterior spinal artery syndrome after diagnostic blockade of the right C6-nerve root. Pain 91: 397-399.

38. Wallace MA, Fukui MB, Williams RL, Ku A, Baghai P (2007) Complications of cervical selective nerve root blocks performed with fluoroscopic guidance. AJR Am J Roentgenol 188: 1218-1221.

39. Rathmell JP, Aprill C, Bogduk N (2004) Cervical transforaminal injection of steroids. Anesthesiology 100: 1595-1600.

40. Tripathi M, Nath SS, Gupta RK (2005) Paraplegia after intracord injection during attempted epidural steroid injection in an awakepatient. Anesth Analg 101: 1209-1211, table of contents.

41. Kainer MA, Reagan DR, Nguyen DB, Wiese AD, Wise ME, et al. (2012) Fungal infections associated with contaminated methylprednisolone in Tennessee. N Engl J Med 367: 2194-2203.

42. U.S. Food and Drug Administration. Drug Safety Communications. FDA Drug Safety Communication: FDA requires label changes to warn of rare but serious neurologic problems after epidural corticosteroid injections for pain. 
43. Manchikanti L, Candido KD, Singh V, Gharibo CG, Boswell MV, et al. (2014) Epidural steroid warning controversy still dogging FDA. Pain Physician 17: E451-474.

44. Peloso PMJ, Gross A, Haines T, Trinh K, Goldsmith CH et al (2007) Cervical Overview Group. Medicinal and injection therapies for mechanical neck disorders. Cochrane Database Syst Rev 3: CD000319.

45. Manchikanti L, Singh V, Derby R, Schultz DM, Benyamin RM, et al. (2008) Reassessment of evidence synthesis of occupational medicine practice guidelines for interventional pain management. Pain Physician 11: 393-482.

46. Manchikanti L, Falco FJ, Singh V, Benyamin RM, Racz GB et al (2013) An update of comprehensive evidence-based guidelines for interventional techniques of chronic spinal pain. Part I. Introduction and general considerations. Pain Physician 16: S1-S48.

47. Liberati A, Altman DG, Tetzlaff J, Mulrow C, Gøtzsche PC et al (2009) The PRISMA statement for reporting systematic reviews and metaanalyses of studies that evaluate health care interventions: Explanation and elaboration. Ann Intern Med 151: W65-W94.

48. Furlan AD, Pennick V, Bombardier C, van Tulder M; Editorial Board, Cochrane Back Review Group (2009) 2009 updated method guidelines for systematic reviews in the Cochrane Back Review Group. Spine (Phila Pa 1976) 34: 1929-1941.

49. Manchikanti L, Hirsch JA, Cohen SP, Heavner JE, Falco FJE et al (2014) Assessment of methodologic quality of randomized trials of interventional techniques: Development of an interventional pain management specific instrument. Pain Physician 17: E263-E290.

50. Manchikanti L, Falco FJ, Benyamin RM, Kaye AD, Boswell MV, et al. (2014) A modified approach to grading of evidence. Pain Physician 17: E319-325.

51. Manchikanti L, Cash KA, Pampati V, Wargo BW, Malla Y (2013) A randomized, double-blind, active control trial of fluoroscopic cervical interlaminar epidural injections in chronic pain of cervical disc herniation: results of a 2-year follow-up. Pain Physician 16: 465-478.

52. Manchikanti L, Cash KA2, Pampati V2, Malla Y2 (2014) Two-year follow-up results of fluoroscopic cervical epidural injections in chronic axial or discogenic neck pain: a randomized, double-blind, controlled trial. Int J Med Sci 11: 309-320.

53. Manchikanti L, Malla Y, Cash KA, McManus CD, Pampati V (2012) Fluoroscopic epidural injections in cervical spinal stenosis: Preliminary results of a randomized, double-blind, active control trial. Pain Physician 15: E59-E70.

54. Manchikanti L, Malla Y, Cash KA, McManus CD, Pampati V et al (2012) Fluoroscopic cervical interlaminar epidural injections in managing chronic pain of cervical post-surgery syndrome: Preliminary results of a randomized, double-blind active control trial. Pain Physician 15: 13-26.

55. Castagnera L, Maurette P, Pointillart V, Vital JM, Erny P, et al. (1994) Long-term results of cervical epidural steroid injection with and without morphine in chronic cervical radicular pain. Pain 58: 239-243.

56. Stav A, Ovadia L, Sternberg A, Kaadan M, Weksler N (1993) Cervical epidural steroid injection for cervicobrachialgia. Acta Anaesthesiol Scand 37: 562-566.

57. Pasqualucci A, Varrassi G, Braschi A, Peduto VA, Brunelli A, et al. (2007) Epidural local anesthetic plus corticosteroid for the treatment of cervical brachial radicular pain: single injection versus continuous infusion. Clin J Pain 23: 551-557.

58. Shakir A, Ma V, Mehta B (2011) Prediction of therapeutic response to cervical epidural steroid injection according to distribution of radicular pain. Am J Phys Med Rehabil 90: 917-922.

59. Lin EL, Lieu V, Halevi L, Shamie AN, Wang JC (2006) Cervical epidural steroid injections for symptomatic disc herniations. J Spinal Disord Tech 19: $183-186$.

60. Lee JW, Park KW, Chung SK, Yeom JS, Kim KJ et al (2009) Cervical transforaminal epidural steroid injection for the management of cervical radiculopathy: A comparative study of particulate versus non-particulate steroids. Skeletal Radiol 38: 1077-1082.
61. Marawar S, Girardi FP, Sama AA, Ma Y, Gaber-Baylis LK, et al. (2010) National trends in anterior cervical fusion procedures. Spine (Phila Pa 1976) 35: 1454-1459.

62. Patil PG, Turner DA, Pietrobon R (2005) National trends in surgical procedures for degenerative cervical spine disease: 1990-2000. Neurosurgery 57: 753-758.

63. Irwin ZN, Hilibrand A, Gustavel M, McLain R, Shaffer W et al (2005) Variation in surgical decision making for degenerative spinal disorders. Part II: Cervical spine. Spine (Phila Pa 1976) 30: 2214-2219.

64. Greiner-Perth R, Allam Y, El-Saghir H, Röhl F, Franke J, et al. (2009) Analysis of reoperations after surgical treatment of degenerative cervical spine disorders: a report on 900 cases. Cent Eur Neurosurg 70: 3-8.

65. Helgeson MD, Albert TJ (2012) Surgery for failed cervical spine reconstruction. Spine (Phila Pa 1976) 37: E323-327.

66. Singh K, Nandyala SV, Marquez-Lara A, Fineberg SJ (2014) Epidemiological trends in the utilization of bone morphogenetic protein in spinal fusions from 2002 to 2011. Spine (Phila Pa 1976) 39: 491-496.

67. Marquez-Lara A, Nandyala SV, Fineberg SJ, Singh K (2014) Current trends in demographics, practice, and in-hospital outcomes in cervical spine surgery: a national database analysis between 2002 and 2011. Spine (Phila Pa 1976) 39: 476-481.

68. Oglesby M, Fineberg SJ, Patel AA, Pelton MA, Singh K (2013) Epidemiological trends in cervical spine surgery for degenerative diseases between 2002 and 2009. Spine (Phila Pa 1976) 38: 1226-1232.

69. Nandyala SV, Marquez-Lara A, Fineberg SJ, Singh K (2014) Comparison between cervical total disc replacement and anterior cervical discectomy and fusion of 1 to 2 levels from 2002 to 2009. Spine (Phila Pa 1976) 39: 53-57.

70. Veeravagu A, Cole T, Jiang B, Ratliff JK (2013) Revision rates and complication incidence in single- and multilevel anterior cervical discectomy and fusion procedures: An administrative database study. Spine J Oct 11. [Epub ahead of print].

71. Pinto RZ, Maher CG, Ferreira ML, Hancock M, Oliveira VC, et al. (2012) Epidural corticosteroid injections in the management of sciatica: a systematic review and meta-analysis. Ann Intern Med 157: 865-877.

72. Manchikanti L, Benyamin RM, Falco FJ, Kaye AD, Hirsch JA (2014) Do Epidural Injections Provide Short- and Long-term Relief for Lumbar Disc Herniation? A Systematic Review. Clin Orthop Relat Res .

73. Manchikanti L, Buenaventura RM, Manchikanti KN, Ruan X, Gupta S, et al. (2012) Effectiveness of therapeutic lumbar transforaminal epidural steroid injections in managing lumbar spinal pain. Pain Physician 15: E199-245.

74. Manchikanti L, Falco FJ, Hirsch JA (2012) Epidural corticosteroid injections in the management of sciatica. Ann Intern Med 157: 865-877.

75. Parr AT, Manchikanti L, Hameed H, Conn A, Manchikanti KN, et al. (2012) Caudal epidural injections in the management of chronic low back pain: a systematic appraisal of the literature. Pain Physician 15: E159-198.

76. Benyamin RM, Manchikanti L, Parr AT, Diwan SA, Singh V et al (2012) The effectiveness of lumbar interlaminar epidural injections in managing chronic low back and lower extremity pain. Pain Physician 15: E363E404.

77. MacVicar J, King W, Landers MH, Bogduk N (2013) The effectiveness of lumbar transforaminal injection of steroids: a comprehensive review with systematic analysis of the published data. Pain Med 14: 14-28.

78. Bicket MC, Gupta A, Brown CH 4th, Cohen SP (2013) Epidural injections for spinal pain: a systematic review and meta-analysis evaluating the "control" injections in randomized controlled trials. Anesthesiology 119: 907-931.

79. Macedo LG, Elkins MR, Maher CG, Moseley AM, Herbert RD, et al. (2010) There was evidence of convergent and construct validity of Physiotherapy Evidence Database quality scale for physiotherapy trials. J Clin Epidemiol 63: 920-925. 
80. Staal JB, de Bie RA, de Vet HC, Hildebrandt J, Nelemans P (2009) Injection therapy for subacute and chronic low back pain: an updated Cochrane review. Spine (Phila Pa 1976) 34: 49-59.

81. Chou R, Huffman L (2009) Guideline for the Evaluation and Management of Low Back Pain: Evidence Review. American Pain Society, Glenview, IL.

82. Manchikanti L, Datta S, Gupta S, Munglani R, Bryce DA, et al. (2010) A critical review of the American Pain Society clinical practice guidelines for interventional techniques: part 2. Therapeutic interventions. Pain Physician 13: E215-264.

83. American College of Occupational and Environmental Medicine (ACOEM) (2007) Low back Disorders. In: Occupational Medicine Practice Guidelines: Evaluation and Management of Common Health Problems and Functional Recovery of Workers, Second Edition. American College of Occupational and Environmental Medicine Press, Elk Grove Village.

84. Manchikanti L, Singh V, Derby R, Schultz DM, Benyamin RM, et al. (2008) Reassessment of evidence synthesis of occupational medicine practice guidelines for interventional pain management. Pain Physician 11: 393-482.

85. Howick J, Bishop FL, Heneghan C, Wolstenholme J, Stevens S, et al. (2013) Placebo use in the United kingdom: results from a national survey of primary care practitioners. PLoS One 8: e58247.

86. Hróbjartsson A, Gøtzsche PC (2010) Placebo interventions for all clinical conditions. Cochrane Database Syst Rev : CD003974.

87. Manchikanti L, Benyamin RM, Falco FJ, Caraway DL, Datta S, et al. (2012) Guidelines warfare over interventional techniques: is there a lack of discourse or straw man? Pain Physician 15: E1-1E26.

88. Manchikanti L, Giordano J, Fellows B, Hirsch JA (2011) Placebo and nocebo in interventional pain management: a friend or a foe--or simply foes? Pain Physician 14: E157-175.

89. Manchikanti L, Cash KA, McManus CD, Pampati V (2012) Fluoroscopic caudal epidural injections in managing chronic axial low back pain without disc herniation, radiculitis, or facet joint pain. J Pain Res 5: 381-390.

90. Manchikanti L, Singh V, Cash KA, Pampati V, Damron KS, et al. (2012) Effect of fluoroscopically guided caudal epidural steroid or local anesthetic injections in the treatment of lumbar disc herniation and radiculitis: a randomized, controlled, double blind trial with a two-year follow-up. Pain Physician 15: 273-286.

91. Manchikanti L, Singh V, Cash KA, Pampati V, Datta S (2012) Fluoroscopic caudal epidural injections in managing post lumbar surgery syndrome: two-year results of a randomized, double-blind, active-control trial. Int J Med Sci 9: 582-591.

92. Manchikanti L, Cash KA, McManus CD, Pampati V, Fellows B (2012) Results of 2-year follow-up of a randomized, double-blind, controlled trial of fluoroscopic caudal epidural injections in central spinal stenosis. Pain Physician 15: 371-384.

93. Manchikanti L, Singh V, Cash KA, Pampati V, Falco FJ (2014) A randomized, double-blind, active-control trial of the effectiveness of lumbar interlaminar epidural injections in disc herniation. Pain Physician 17: E61-74.

94. Manchikanti L, Cash KA, McManus CD, Pampati V, Benyamin RM (2013) A randomized, double-blind, active-controlled trial of fluoroscopic lumbar interlaminar epidural injections in chronic axial or discogenic low back pain: results of 2-year follow-up. Pain Physician 16: E491-504.

95. Manchikanti L, Cash KA, McManus CD, Damron KS, Pampati V et al (2014) A randomized, double-blind controlled trial of lumbar interlaminar epidural injections in central spinal stenosis: 2-year followup. Int J Phys Med Rehab 2: 179.

96. Sato C, Sakai A, Ikeda Y, Suzuki H, Sakamoto A (2008) The prolonged analgesic effect of epidural ropivacaine in a rat model of neuropathic pain. Anesth Analg 106: 313-320, table of contents.
97. Tachihara H, Sekiguchi M, Kikuchi S, Konno S (2008) Do corticosteroids produce additional benefit in nerve root infiltration for lumbar disc herniation? Spine (Phila Pa 1976) 33: 743-747.

98. Cui W, Li Y, Li S, Wang R, Li J (2010) Systemic administration of lidocaine reduces morphine requirements and postoperative pain of patients undergoing thoracic surgery after propofol-remifentanil based anaesthesia. Eur J Anaesthesiol 27: 41-46.

99. Koppert W, Zeck S, Sittl R, Likar R, Knoll R, et al. (1998) Low-dose lidocaine suppresses experimentally induced hyperalgesia in humans. Anesthesiology 89: 1345-1353.

100. Koppert W, Ostermeier N, Sittl R, Weidner C, Schmelz M (2000) Lowdose lidocaine reduces secondary hyperalgesia by a central mode of action. Pain 85: 217-224.

101. Kawamata M, Takahashi T, Kozuka Y, Nawa Y, Nishikawa K, et al. (2002) Experimental incision-induced pain in human skin: effects of systemic lidocaine on flare formation and hyperalgesia. Pain 100: 77-89.

102. Hollmann MW, Durieux ME (2000) Local anesthetics and the inflammatory response: a new therapeutic indication? Anesthesiology 93: 858-875.

103. Sugimoto M, Uchida I, Mashimo $T$ (2003) Local anaesthetics have different mechanisms and sites of action at the recombinant $\mathrm{N}$-methylD-aspartate (NMDA) receptors. Br J Pharmacol 138: 876-882.

104. Alimasi W, Sawaji Y, Endo K, Yorifuji M, Suzuki H, et al. (2013) Regulation of nerve growth factor by anti-inflammatory drugs, a steroid, and a selective cyclooxygenase 2 inhibitor in human intervertebral disc cells stimulated with interleukin-1. Spine (Phila Pa 1976) 38: 1466-1472.

105. Minamide A, Tamaki T, Hashizume H, Yoshida M, Kawakami M, et al. (1998) Effects of steroid and lipopolysaccharide on spontaneous resorption of herniated intervertebral discs. An experimental study in the rabbit. Spine (Phila Pa 1976) 23: 870-876.

106. Hayashi N, Weinstein JN, Meller ST, Lee HM, Spratt KF, et al. (1998) The effect of epidural injection of betamethasone or bupivacaine in a rat model of lumbar radiculopathy. Spine (Phila Pa 1976) 23: 877-885.

107. Slucky AV, Sacks MS, Pallares VS, Malinin TI, Eismont FJ (1999) Effects of epidural steroids on lumbar dura material properties. J Spinal Disord 12: $331-340$

108. Cluff R, Mehio AK, Cohen SP, Chang Y, Sang CN, et al. (2002) The technical aspects of epidural steroid injections: a national survey. Anesth Analg 95: 403-408, table of contents.

109. Stojanovic MP, Vu TN, Caneris O, Slezak J, Cohen SP, et al. (2002) The role of fluoroscopy in cervical epidural steroid injections: an analysis of contrast dispersal patterns. Spine (Phila Pa 1976) 27: 509-514.

110. Kim KS, Shin SS, Kim TS, Jeong CY, Yoon MH et al (2009) Fluoroscopically guided cervical interlaminar epidural injections using the midline approach: An analysis of epidurography contrast patterns. Anesth Analg 108: 1658-1661.

111. Goel A, Pollan JJ (2006) Contrast flow characteristics in the cervical epidural space: an analysis of cervical epidurograms. Spine (Phila Pa 1976) 31: 1576-1579.

112. Kirpalani D, Mitra R (2011) Is chronic opioid use a negative predictive factor for response to cervical epidural steroid injections? J Back Musculoskelet Rehabil 24: 123-127.

113. Strub WM, Brown TA, Ying J, Hoffmann M, Ernst RJ, et al. (2007) Translaminar cervical epidural steroid injection: short-term results and factors influencing outcome. J Vasc Interv Radiol 18: 1151-1155.

114. Fish DE, Kobayashi HW, Chang TL, Pham Q (2009) MRI prediction of therapeutic response to epidural steroid injection in patients with cervical radiculopathy. Am J Phys Med Rehabil 88: 239-246.

115. Shakir A, Ma V, Mehta B (2011) Prediction of therapeutic response to cervical epidural steroid injection according to distribution of radicular pain. Am J Phys Med Rehabil 90: 917-922.

116. Ferrante FM, Wilson SP, Iacobo C, Orav EJ, Rocco AG, et al. (1993) Clinical classification as a predictor of therapeutic outcome after cervical epidural steroid injection. Spine (Phila Pa 1976) 18: 730-736. 
Citation: Manchikanti L, Nampiaparampil DE, Candido KD, Bakshi S, Grider JS, Falco FJS, et al. (2014) Do Cervical Epidural Injections Provide Long-Term Relief in Neck And Upper Extremity Pain? A Systematic Review. J Spine 3: 177. doi:10.4172/2165-7939.1000177

Page 13 of 13

117. Kwon JW, Lee JW, Kim SH, Choi JY, Yeom JS, et al. (2007) Cervical interlaminar epidural steroid injection for neck pain and cervical radiculopathy: effect and prognostic factors. Skeletal Radiol 36: 431-436.

118. Thielke SM, Turner JA, Shortreed SM, Saunders K, Leresche L, et al. (2014) Do patient-perceived pros and cons of opioids predict sustained higher-dose use? Clin J Pain 30: 93-101.

119. Manchikanti L, Abdi S, Atluri S, Balog CC, Benyamin RM et al (2012) American Society of Interventional Pain Physicians (ASIPP) guidelines for responsible opioid prescribing in chronic non-cancer pain: Part I Evidence assessment. Pain Physician 15: S1-S66.

120. Manchikanti L, Abdi S, Atluri S, Balog CC, Benyamin RM et al (2012) American Society of Interventional Pain Physicians (ASIPP) guidelines for responsible opioid prescribing in chronic non-cancer pain: Part 2 Guidance. Pain Physician 15: S67-S116.

121. Manchikanti L, Cash KA, Malla Y, Pampati V, Fellows B (2013) A prospective evaluation of psychotherapeutic and illicit drug use in patients presenting with chronic pain at the time of initial evaluation. Pain Physician 16: E1-1E13.

122. Chen B, Rispoli L, Stitik TP, Foye PM, Georgy JS (2014) Optimal needle entry angle for cervical transforaminal epidural injections. Pain Physician 17: 139-144.

123. Candido KD, Knezevic N' (2013) Cervical epidural steroid injections for the treatment of cervical spinal (neck) pain. Curr Pain Headache Rep 17: 314.

124. Ma DJ, Gilula LA, Riew KD (2005) Complications of fluoroscopically guided extraforaminal cervical nerve blocks. An analysis of 1036 injections. J Bone Joint Surg Am 87: 1025-1030.

125. Shipley K, Riew KD, Gilula LA (2014) Fluoroscopically guided extraforaminal cervical nerve root blocks: analysis of epidural flow of the injectate with respect to needle tip position. Global Spine J 4: 7-12. 